$\xi^{2}=-$ 줄

\title{
Curie depth and heat flow analysis of Ikot Ekpene and environs, Eastern Niger Delta Basin, using airborne magnetic data
}

\author{
Uche Iduma ${ }^{1}$, Ibe Stephen Onyejiuwaka ${ }^{2 *}$, Nwokeabia Charity Nkiru ${ }^{3}$ \\ ${ }^{1}$ Department of Geophysics, Kelmageodynamics Limited, Abuja, Nigeria \\ ${ }^{2}$ Department of Physics, Federal University Otuoke, Bayelsa State, Nigeria \\ ${ }^{3}$ Department of Geophysics, Nnamdi Azikiwe University Awka, Anambra State, Nigeria \\ *Corresponding author E-mail: stphnibe@yahoo.com
}

\begin{abstract}
Aeromagnetic dataset over Ikot Ekpene and environs, Eastern Niger Delta Basin, was processed to compute the basement depth, Curie isotherm depth, geothermal gradient and heat flow within the area in order to investigate the depth to magnetic sources, geothermal prospect and the hydrocarbon potential of the place. The adopted computational method transformed the spatial data into frequency domain and provided a relationship between radially average power spectrum of the magnetic anomalies and the depths to respective sources. The results of the analysis showed that the depths to centroids and top boundaries range from 7.84 to $13.38 \mathrm{~km}$ and 0.233 to $0.459 \mathrm{~km}$ respectively. Curie depths within the basin undulate and vary between 15.42 and $26.49 \mathrm{~km}$. The geothermal gradients range between 20.758 and $35.649^{\circ} \mathrm{C} / \mathrm{km}$ while the corresponding heat flow is about $51.896 \mathrm{mWm}^{-2}$ within east of Ikono, north of Mbak and west of Abak Areas and $89.124 \mathrm{mWm}^{-2}$ within Amawum, Ndoro, Isiala, Ogbuebule and east of Uyo Areas. Based on the computed sedimentary thicknesses, high geothermal gradients and delineated major faults and fractures which could serve as migratory pathway for hydrocarbon or hydrothermal fluid, some parts of the study area have been demarcated for geothermal prospect and detail hydrocarbon exploration.
\end{abstract}

Keywords: Curie Depth; Geothermal Gradient; Sedimentary Thicknesses; Major Faults; Oil Window.

\section{Introduction}

Lithospheric thermal gradients are rarely distributed uniformly and are sometimes contaminated by local thermal anomalies; they are often estimated from near-surface heat-flow measurements. Adequate knowledge of the thermal structure of the lithosphere is required for a wide variety of geodynamic investigations, including rock deformation, mineral phase boundaries, rates of chemical reactions, electrical conductivity, magnetic susceptibility, seismic velocity and mass density (Chapman and Furlong, 1992). Geothermal gradients are very useful; as indicators of subsurface temperature distribution, in the understanding of regional and sub-regional tectonics and in the assessment of geothermal resource potentials of an area (Nwankwo et al. 2009). Temperature is one of the primary factors controlling hydrocarbon generation, sediment diagenesis and migration of hydrocarbons and other pore fluids (Nwankwo, 2007). Various studies have shown correlations between Curie-temperature depths and average crustal temperatures, leading to viable conclusions regarding lithospheric thermal conditions in a number of regions around the world.

Early researches on Curie point depth determination using spectral analysis of geomagnetic data are those of Okubo et al. (1985; 1989), Okubo et al. (2003), Trifonova et al. (2009) and Maden (2009). These studies had shown great successes made in deriving the depth to certain geological structures such as magnetic basement. Spector and Grant (1970) stated that the depth factor invariably dominates the shape of the radially averaged power spectrum of the magnetic data.

According to Stefan and Vijay (1996), depth estimation from potential field using spectral analysis requires a realistic assumption of the statistical properties of the source distributions. This research is aimed at estimating the depth to magnetic sources and computing the Curie isotherm depth, geothermal gradient, heat flow and sedimentary thickness within Ikot Ekpene and its environs, in the Eastern Niger Delta Basin, South-south and South-east Nigeria, in order to investigate the geothermal prospect and the hydrocarbon potential of the area. This part of the Eastern Niger Delta Basin (study area), has in the past received limited attention in geophysical studies compared with other parts of the basin. This may be due to lack of immediate geologic and economic values, though it is fast becoming an important study area for geoscientists due to its possible hydrocarbon potential. Geophysical study in the area is minimal, with no records of crustal temperature studies. Curie isotherm depth with geothermal and heat flow assessment would significantly compliment the geological information of the area to bridge the gap of lacking crustal temperature information; these give better understanding of the geology and hydrocarbon potential of the area.

Tselentis (1991) stated that the study of variations in Curie isotherm depth of an area has provided valuable information about the regional temperature distribution at depth and the concentration of subsurface geothermal energy. It was also stated that a region with sig- 
nificant geothermal energy is characterised by an anomalous high temperature gradient and heat flow. Hisarli (1996) observed that one of the important parameters that determines the relative depth of the Curie isotherm with respect to sea level is the local thermal gradient; that is, heat flow. Hence, geothermically active areas are associated with shallow Curie point depth (Nuri et al. 2005). Temperature inside the earth directly controls most of the geodynamic processes that are visible on the surface (Nwankwo et al. 2011).

\section{The study area}

The area is bounded by longitudes $7^{\circ} 30^{\prime} 00^{\prime \prime} \mathrm{E}$ to $8^{\circ} 00^{\prime} 00^{\prime \prime} \mathrm{E}$ and latitudes $5^{\circ} 00^{\prime} 00^{\prime \prime} \mathrm{N}$ to $5^{\circ} 30^{\prime} 00^{\prime \prime} \mathrm{N}$ (Fig. 1). It shares boundary with Ovim and Nguso in the north, Ikot Etim and Ikot Eba in the south, Ndealiche and Ugep in the east and Okigwe and Owerrinta in the west. The area can be accessed through Abakaliki - Afikpo Expressway, Umuahia - Afikpo Expressway and Ikot Ekpene - Afikpo Expressway. It falls within the humid tropical region with two distinct seasons, the rainy season, from March to October, and dry season, from November to March.

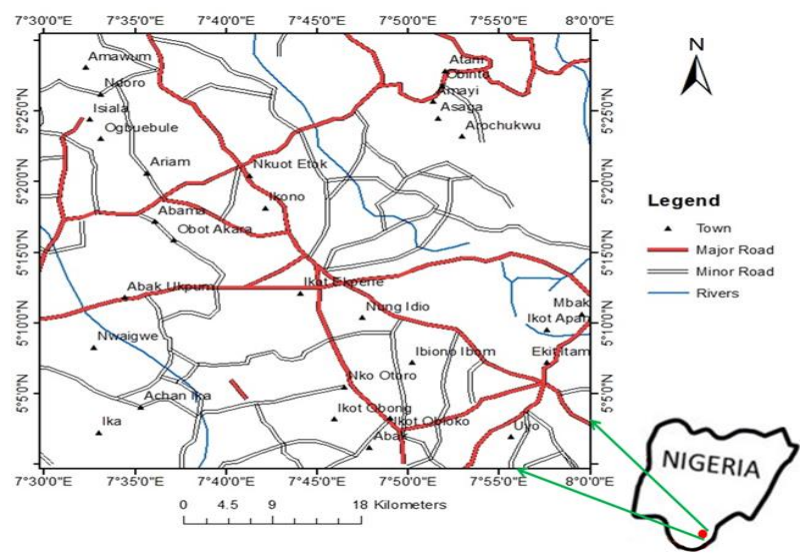

Fig. 1: Accessibility Map of the Study Area

The study area is located in the Eastern Niger Delta Sedimentary Basin. The Niger Delta Basin, occupying a total area of about 300,000 $\mathrm{km}^{2}$, is an extensional rift basin located in the Niger Delta and the Gulf of Guinea on the passive continental margin near the western coast of Nigeria (Tuttle et al. 1999) and partly extends to Cameroon, Equatorial Guinea and São Tomé and Príncipe. Oceanic basement rock of pre-rift time period and basaltic in composition is the oldest rock in the basin. Also, closer to the coast is the Precambrian continental basement. This basin was formed in the Tertiary period from the interplay between subsidence and deposition arising from a succession of transgressions and regressions of the sea (Hosper, 1965). It was formed by a failed rift junction during separation of the South American plate and the African plate, as well as the opening of the South Atlantic.

The sediment fill of the basin has a depth between $9-12 \mathrm{~km}$ (Fatoke, 2010) and it is composed of several different geologic formations that indicate how this basin was formed, as well as the regional and large scale tectonics of the area. The formation of the present Niger Delta started during early Paleocene as a result of the built up of fine grained sediments eroded and transported to the area by the River Niger and its tributaries. Three lithostratigraphic units are distinguishable in the Tertiary Niger Delta (Short and Stauble, 1967). The basal Akata Formation of about $7000 \mathrm{~m}$ in thickness, which is predominantly marine prodelta shale, is overlain by about $3700 \mathrm{~m}$ thick paralic sand/shale sequence of the Agbada Formation (Tuttle et al. 1999). The Akata Formation is the source rock in the sedimentary basin. The topmost section is the continental upper deltaic plain sands - the Benin Formation, estimated to be about $2000 \mathrm{~m}$ in thickness (Tuttle et al. 1999). A separate member of Benin Formation, the Afam Clay Member, is recognized in the Port Harcourt Area which is interpreted to be an ancient valley fill formed in Miocene sediments (Short and Stauble, 1967). These Formations are underlain by various types of Quaternary deposits. According to Osakuni and Abam (2004), these Quaternary sediments are largely alluvial and hydromorphic soils and lacustrine sediments of Pleistocene age. The Quaternary geologic units of the Niger Delta Area are shown in Table 1.

Table 1: Quaternary deposits of the Niger Delta (Adopted from Ibe and Anekwe, 2018)

\begin{tabular}{lll}
\hline Geologic Unit & Lithology & Age \\
\hline Alluvium & Gravel, Sand, clay, silt & \\
Freshwater Backswamp, meander belt & Sand, clay, some silt, gravel & Quaternary \\
Saltwater Mangrove Swamp and backswamp & Medium-fine sands, clay and some silt & \\
Active/abandoned beach ridges & Sand, clay, and some silt & \\
Sombreiro-warri deltaic plain & Sand, clay, and some silt & Miocene-Recent \\
Benin Formation (Coastal Plain Sand) & Coastal to medium sand; subordinate silt and clay & Mixes \\
Agbada Formation & lenses & Eocene-Recent \\
Akata Formation & Mixture of sand, clay and silt & Paleocene \\
\hline
\end{tabular}

The depositional pattern which accompanied the accumulation of sediments during the formation of the delta, gave rise to structural traps (growth faults and roll-over anticlines) in the Agbada Formation (Nwankwoala and Ngah, 2014). Virtually all the hydrocarbon accumulations in the Niger Delta occur in the sands and sandstones of the Agbada Formation where they are trapped by the rollover anticlines related to the growth fault development (Ekweozor and Daukoru, 1994). 


\section{Materials, method, data processing and enhancement}

\subsection{Data acquisition}

The aeromagnetic dataset used for this study is from the high-resolution airborne magnetic survey coverage in Nigeria in 2009 carried out by Fugro Airborne Service. The aeromagnetic map of total magnetic field intensity of sheet number 322 was used. The data, which cover an area of about $3,025 \mathrm{~km}^{2}$ were acquired along a series of NW - SE flight lines at $500 \mathrm{~m}$ line spacing, $20 \mathrm{~km}$ tie lines spacing and at $100 \mathrm{~m}$ terrain clearance. The map was published by Nigerian Geological Survey Agency (NGSA), on a scale of 1:100,000. The total magnetic intensity grid was generated using a minimum curvature algorithm at a grid cell size of $100 \mathrm{~m}$. The digitized data were filtered using a low pass Fourier domain sub-routine filter to eliminate unwanted wavelengths and to pass longer wavelengths. Reduction-to-pole (RTP) transformation was applied to the aeromagnetic data to minimize polarity effects. Separation of regional and residual anomaly was done using Trend Analysis in which a linear trend surface was fitted into the total aeromagnetic field data by a Multiple Regression Technique. The linear surface fitted was removed from the regional component to obtain the residual magnetic anomaly map that was interpreted.

Total field $=$ Regional field + Residual field

Residual field $=$ Total field - fitted Surface/Regional field

\subsection{Estimation of the curie point depth}

Fast Fourier Transform (FFT) is the mathematical tool used for the spectral analysis and it applies to regularly spaced data, such as the aeromagnetic data, to calculate and interpret the spectra of the potential field. It transforms magnetic data from space domain to frequency domain. The application of spectra analysis technique to determine the Curie point depth was carried out by separating the effect of different bodies' parameters in the observed magnetic anomaly field (Hisarli, 1996). In this study, FOURPOT (Markku, 2014), which is a Potential field data processing and analysis software, using 2-D Fourier transform, was used to generate the spectral plots. The top boundaries and the centroids of magnetic sources were calculated from the spectra of the magnetic anomalies which were used to estimate the basal depths of magnetic sources. In order to increase the resolution of the resultant depth values, the residual map of the study area was divided into nine blocks of overlapping sections of spectral Cells of $18.3 \mathrm{~km}$ by $18.3 \mathrm{~km}$ (Fig. 2) to accommodate longer wavelengths so that maximum depth could be investigated.

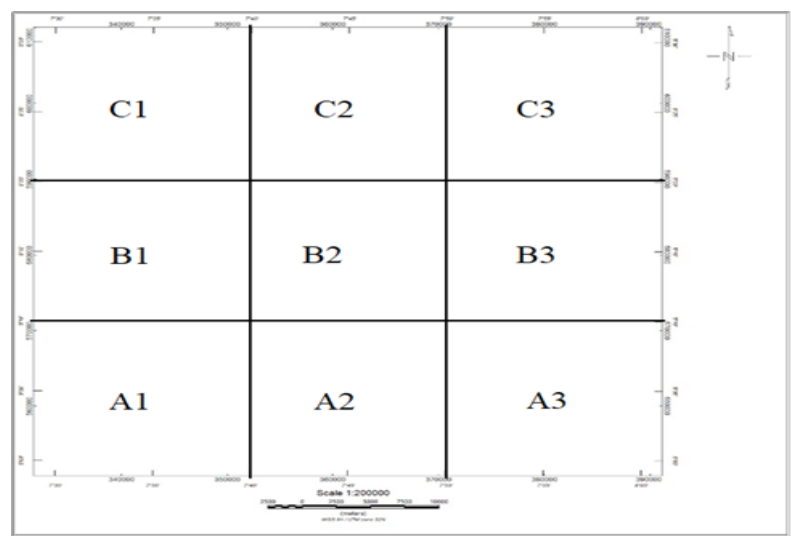

Fig. 2: 2D Grid Map for Spectrum Analysis.

The FOURPOT software transformed the magnetic field data into the radial energy spectrum for each block. To perform this analysis, the average radial energy spectrum was calculated and the graphs of the natural logarithm of energy against frequency were plotted. For each of the plots, the depth to centroid $\left(\mathrm{z}_{0}\right)$ of the magnetic sources was estimated from the slope of the low frequency component part of the energy spectrum, while the depth to the top boundary $\left(z_{t}\right)$ of magnetic sources was estimated from the slope of the high frequency component part of the spectral segment. The computed centroid depth and the depth to the top boundary were used to estimate the basal depth $\left(z_{b}\right)$ using Equation 3 and this is assumed as the Curie point depth (Kasidi and Nur, 2012 and Okubo et al. 1985).

$\mathrm{z}_{\mathrm{b}}=2 \mathrm{z}_{0}-\mathrm{z}_{\mathrm{t}}$

One Dimensional Heat Conductive Model was used to estimate the heat flow and the geothermal gradient. This model is based on the Fourier's law (Kasidi and Nur, 2012) which is based on the following mathematically expressions.

$\mathrm{q}=\mathrm{k} \frac{\mathrm{dT}}{\mathrm{dz}}$

Where $\mathrm{q}=$ quantity of heat flow, $\mathrm{k}=$ coefficient of thermal conductivity, and $\frac{\mathrm{dT}}{\mathrm{dz}}=$ thermal gradient which is assumed constant as no heat enters or leaves above the crust and below the Curie point depth.

Nwankwo and Ekine (2009) defined the Curie temperature $(\theta)$ as:

$\theta=\left(\frac{d T}{d z}\right) z_{b}$

Comparing 4 and 5, we have 


$$
\mathrm{q}=\left(\mathrm{k} \frac{\theta}{\mathrm{z}_{\mathrm{b}}}\right)
$$

This research used equation 6 to estimate the heat flow within the study area after the Curie point depths were calculated. For this estimation to be possible, a standard for Curie point isotherm of $580^{\circ} \mathrm{C}$ and thermal conductivity of $2.5 \mathrm{Wm}^{-1}{ }^{\circ} \mathrm{C}^{-1}$ suggested by Nwankwo et al. (2011) were used. The geothermal gradient was determined from equation 5 as:

$$
\frac{\mathrm{dT}}{\mathrm{dz}}=\frac{\theta}{\mathrm{z}_{\mathrm{b}}}
$$

Where $\frac{\mathrm{dT}}{\mathrm{dz}}=$ Geothermal gradient, $\mathrm{z}_{\mathrm{b}}=$ the basal depth and $\theta=$ the standard temperature of $580^{\circ} \mathrm{C}$.

\section{Results and discussion}

The maps of the total magnetic field intensity (Fig. 3) and residual magnetic anomalies (Fig. 4) of the study area suggest that the total magnetic field and residual anomalies range from 32810.3 to $>32966.8 \mathrm{nT}$ and -61.393 to $100.424 \mathrm{nT}$ respectively. Long wavelengths are observed at the northern, central, eastern and southeastern parts of the study area. The areas of long magnetic anomaly wavelengths are interpreted to have thick sediment cover while areas with short wavelengths observed at the northeastern, northwestern and southwestern parts of the study area indicate areas with thin sediment cover. The residual map, which reflects magnetic sources at shallow depths, enhanced the high frequency bodies within the study area. High frequency bodies are observed at the northeastern, northwestern and southwestern parts of the study area and these are inferred to be signal related to the intrusives associated with the area. The high frequency bodies are observed to be more in occurrences at Uyo, Atani, Obinto, Asaga, Arochukwu, Nwaigwe, Ikot Ekpene, Amawum, Ndoro, Isiala and Ekit Itam Areas.

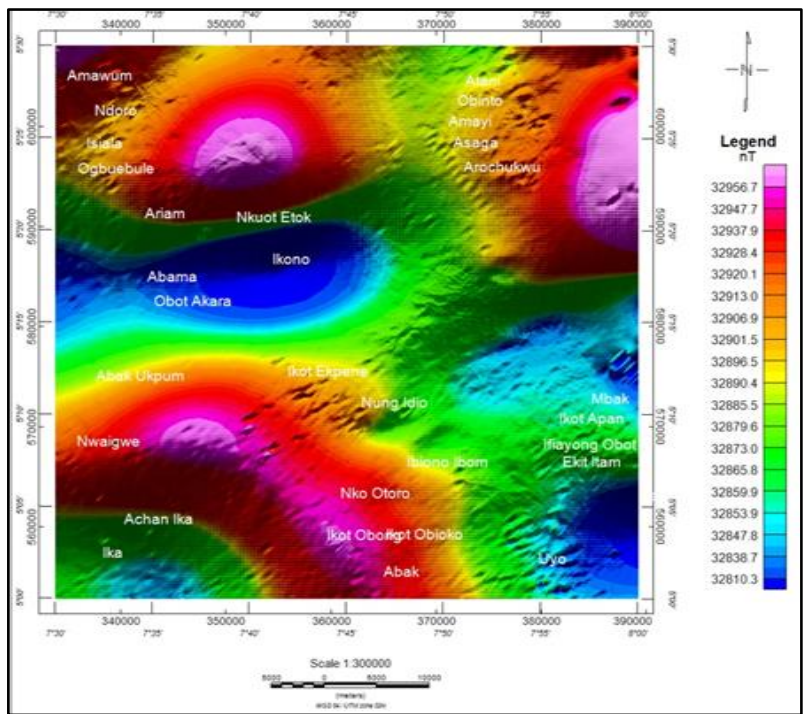

Fig. 3: Total Magnetic Field Intensity Map of the Study Area.

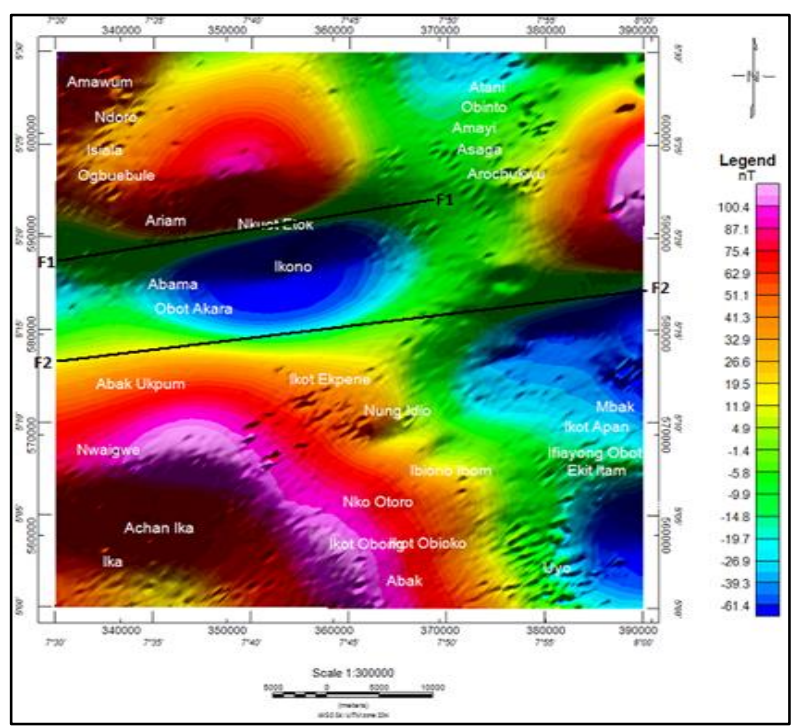

Fig. 4: Residual Magnetic Anomaly Map of the Study Area.

Sharp contacts between high intensity and low intensity magnetic bodies are observed at the northwestern and central parts of the study area; these were interpreted as two major fault systems (F1 and F2) within the area. The fault, F2 stretched across from the western to the 
eastern parts of the area covering a distance of about $56.1 \mathrm{~km}$ within the study area and looks to extend both westward and eastward beyond the area.

Curie depth is the depth that equals the point at which magnetism is lost in the crust. Based on this, the Curie depths were calculated using the depths of the shallowest and deepest sources which were obtained using the centroid method. The spectral analysis carried out on each block (Fig. 2) produced the logarithmic graphs of the spectral energies (Figs. 5 (a) - (i)). The summary of the calculated depths to the centroids $\left(\mathrm{z}_{0}\right)$, depths to the top boundaries $\left(\mathrm{z}_{\mathrm{t}}\right)$, Curie depths $\left(\mathrm{z}_{\mathrm{b}}\right)$, geothermal gradients and heat flow $(\mathrm{q})$, for the nine blocks, is presented in Table 2 .
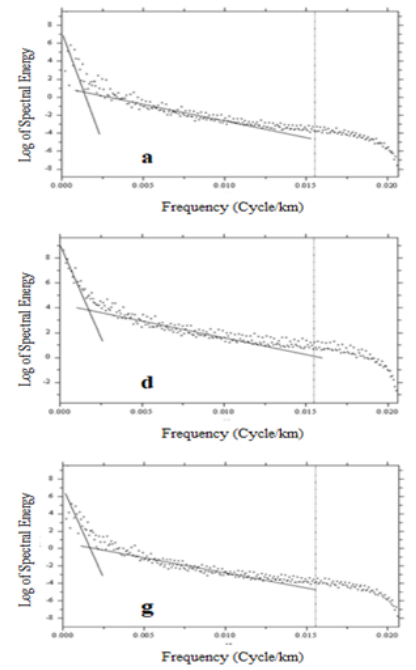

Fig. 5: Spectrum Energy Plot of (a) C1, (b) C2, (c) C3, (d) B1, (e) B2, (f) B3, (g) A1, (h) A2, (i) A3.

Table 2: Calculated Average Depths to Centroids, Top Boundaries, Curie Points and the Corresponding Geothermal Gradients and Heat Flow for the Nine Spectral Blocks

\begin{tabular}{lllll}
\hline $\begin{array}{l}\text { Grid } \\
\text { Name }\end{array}$ & $\begin{array}{l}\text { Centroid Depth } \mathrm{z}_{0} \\
(\mathrm{~m})\end{array}$ & $\begin{array}{l}\text { Depth to Top Boundary } \mathrm{z}_{\mathrm{t}} \\
(\mathrm{m})\end{array}$ & $\begin{array}{l}\text { Curie Point Depth } \mathrm{z}_{\mathrm{b}} \\
(\mathrm{km})\end{array}$ & $\begin{array}{l}\text { Geothermal Gradient } \\
\left({ }^{\circ} \mathrm{C} / \mathrm{Km}\right)\end{array}$ \\
\hline A1 & 9078.459 & 459.233 & 17.69769 & 31.07751099 \\
A2 & 13132.690 & 347.381 & 25.91800 & 21.22077730 \\
A3 & 10772.690 & 262.099 & 21.28327 & 25.84189244 \\
B1 & 9631.756 & 233.339 & 19.03017 & 28.90147136 \\
B2 & 12972.320 & 270.366 & 25.67427 & 21.42222377 \\
B3 & 13380.380 & 265.489 & 26.49528 & 20.75841825 \\
C1 & 10730.360 & 344.646 & 21.11606 & 26.04652079 \\
C2 & 12917.210 & 369.557 & 25.46486 & 21.59839512 \\
C3 & 7839.615 & 251.415 & 15.42782 & 35.654 \\
\hline
\end{tabular}

The depths to the centroids $\left(\mathrm{z}_{0}\right)$ (Fig. 6a) obtained for the study area range from about 7.84 to $13.38 \mathrm{Km}$. Figure 6b shows 3-D basement topography variation within the area. The depths to the top boundaries $\left(\mathrm{z}_{\mathrm{t}}\right)$ of magnetic sources, range from about 0.233 to $0.459 \mathrm{~km}$ (Table 2). Depth to centroid is synonymous with the depth to the deepest point of the sedimentary basin; therefore, the thickest sediment in the study area was delineated within Ikot Ekpene, Mbak, Ibiono Ibom, Abak, Ikot Apan and west of Atani and Obinto parts of the study area. The shallowest sediment depth was delineated within Abak Ukpum, Nwaigwe, Achan Ika, Ika and east of Atani and Obinto parts of the study area.
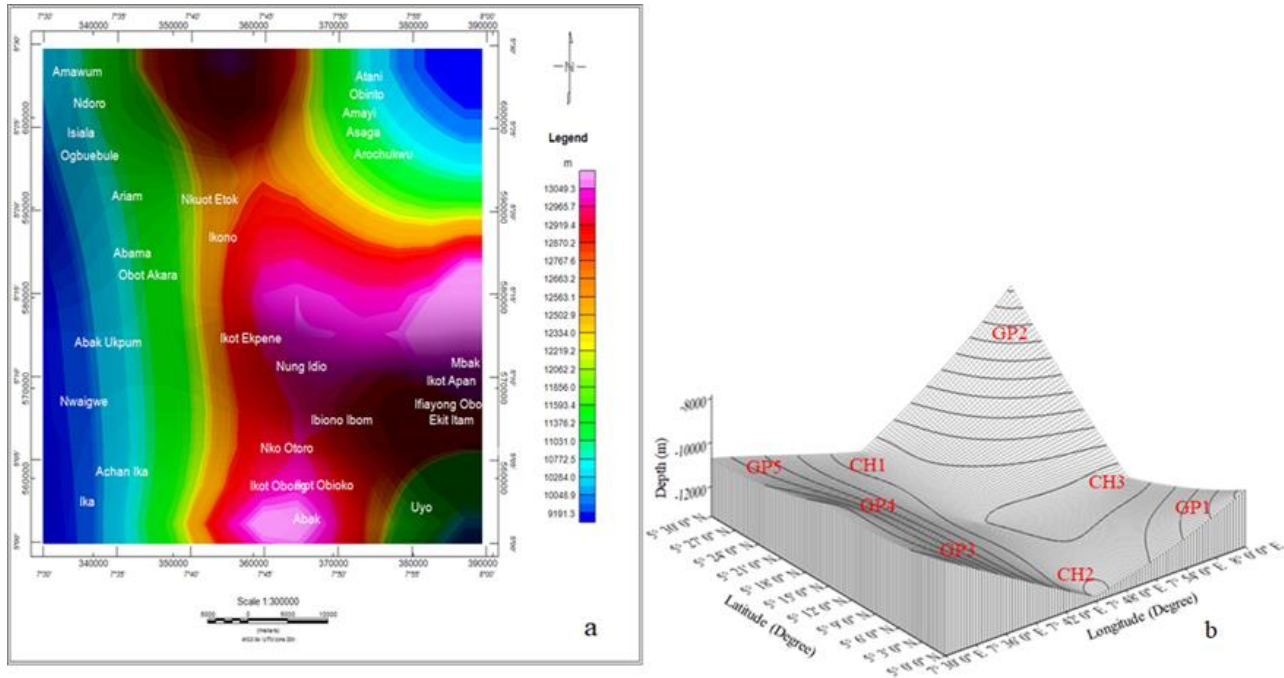

Fig. 6: Maps Showing (a) Depth to Centroid, (b) 3-D Basement Topography Variation. 
The results suggest that Curie isotherm depths (Fig. 7) vary within the study area with minimum depths ranging from about 15.427 to $24.158 \mathrm{~km}$ at Amawum, Ndoro, Isiala, Ogbuebule, Nwaigwe and Abak Ukpum Areas; intermediate depths with range greater than 24.158 to about $25.14 \mathrm{~km}$ at Obot Akara, Nkuot Etok, Achan Ika, Ikot Apan and Mbak Areas; and maximum depths, greater than 25.14 $\mathrm{km}$, at Ikot Ekpene, Nung Idio, east of Ikono, north of Mbak and west of Abak, Atani and Amayi Areas. These results compare fairly well with the Curie depths obtained for Anambra Basin (Onwuemesi, 1997), Upper Benue Trough (Nur et al. (1999), Chad Basin (Nwankwo et al. 2009) and Eastern Niger Delta Basin (Emujakporue and Ekine, 2014). The computed Curie point depths show an average Curie depth of $21.7 \mathrm{~km}$ within the study area. Shallower Curie point depth average of $21.15 \mathrm{~km}$ was delineated at east of Atani, Obinto and Asaga Areas. Previous study (Ibe and Uche, 2018) has shown that these areas have shallow sediment thickness which thins further northeast of Atani, towards the Southwestern Basement Complex of Ugep Area. Shallow Curie Depth was also observed at Uyo axis. The deeper Curie depth anomaly trends in NNE-SSW direction within the study area and could have resulted from isostatic compensation in the region.

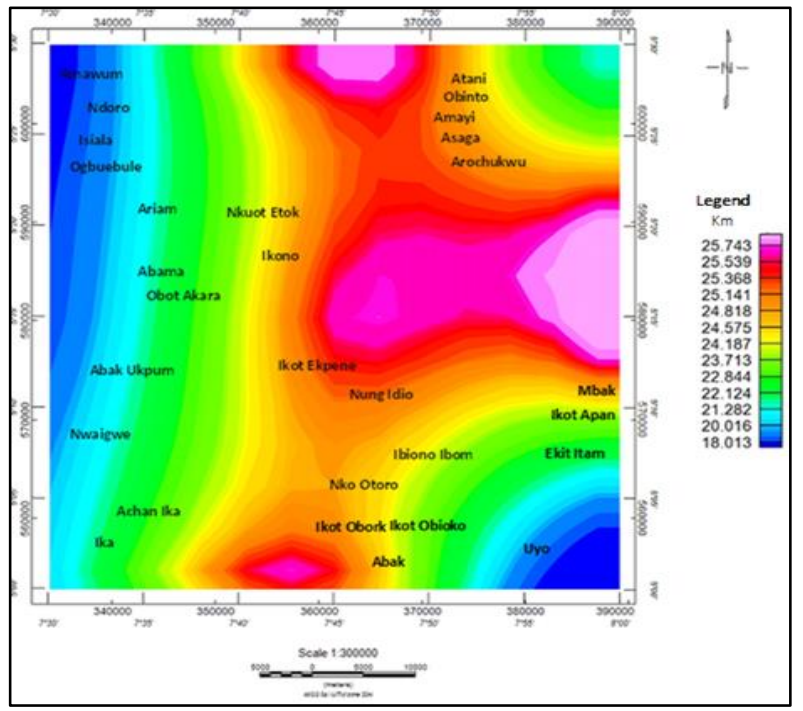

Fig. 7: Curie Depth Map of the Study Area.

The geothermal gradient variation within the study area is presented in Fig. 8 and the corresponding heat flow anomaly is shown in Fig. 9. The results obtained show that geothermal gradient varies between about 20.758 and $35.649{ }^{\circ} \mathrm{C} / \mathrm{km}$. The corresponding mantle heat flow varies from about $51.896 \mathrm{mWm}^{-2}$ to $89.124 \mathrm{mWm}^{-2}$, with the lowest heat delineated within east of Ikono, north of Mbak and west of Abak Areas, while it is highest within Amawum, Ndoro, Isiala, Ogbuebule, and east of Uyo Areas.

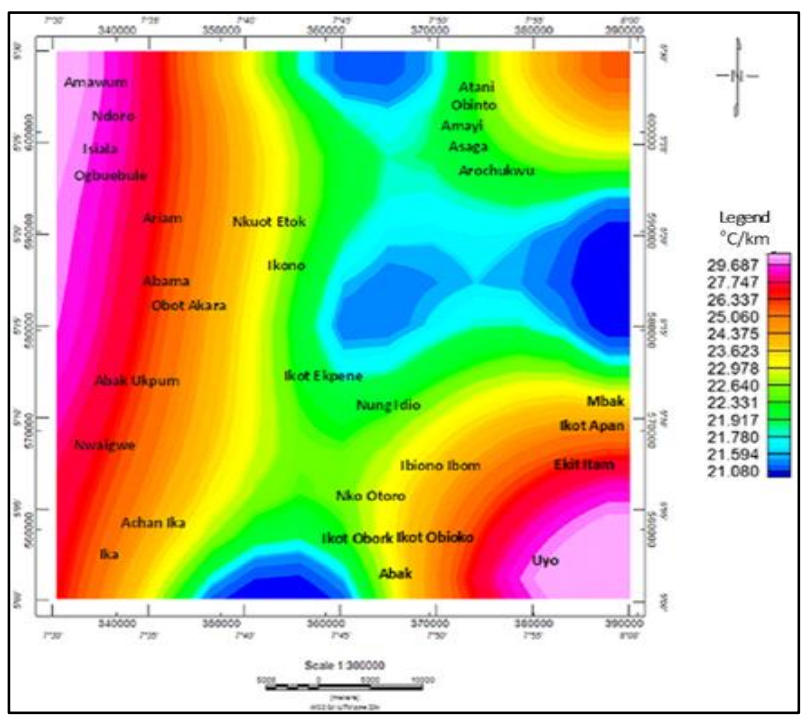

Fig. 8: Geothermal Gradient Variations Map of the Study Area. 


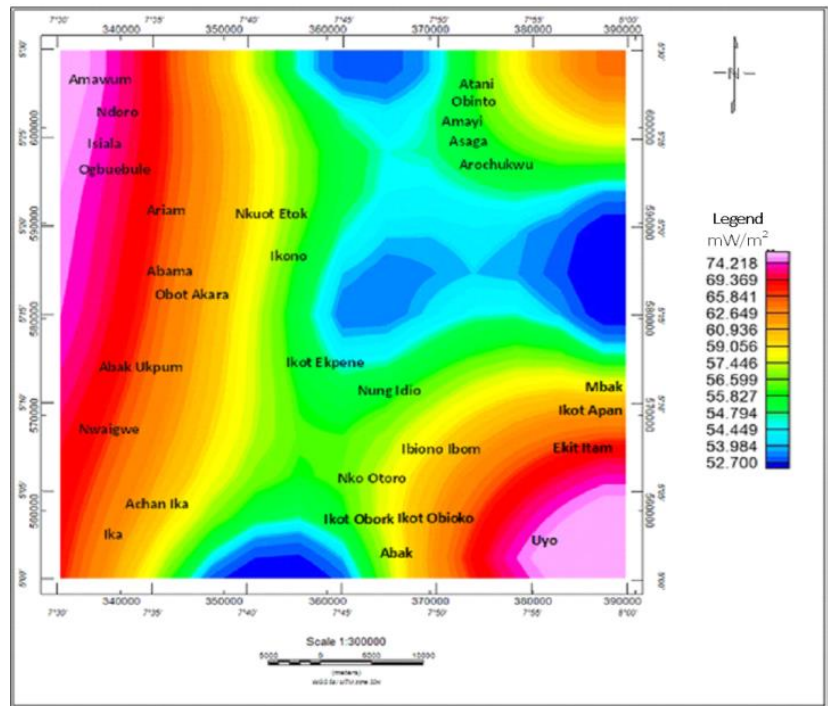

Fig. 9: Heat Flow Anomaly Map of the Study Area.

The geothermal gradient map (Fig. 8) shows regions of high geothermal gradients at Amawum, Ndoro, Isiala, Ogbuebule, Uyo, Abak Ukpum, Nwaigwe, Ika and east of Atani Areas and low geothermal gradients at east of Ikono, north of Mbak, west of Abak, Ikot Ekpene and Nung Idio Areas. This is closely related to the heat flow map (Fig. 9); which implies that most areas of high heat flow correspond to high geothermal gradient. The variation of heat flow within the study area indicates random distribution of magma conduits. The heat flow results obtained in this study compare favourably well with the results of other works on heat flow within Nigeria's Inland Basins (Nwankwo et al. 2009, Kasidi and Nur, 2012 and 2013, Akpabio and Ejedawa, 2010, Anakwuba and Chinwuko, 2015, Nur et al. 1999). The average heat flow obtained in this study is about $70.51 \mathrm{mWm}^{-2}$; this may be considered as typical of continental crust (Jessop et al. 1976). The geothermal prospects of an area are the places with thin layer of thermally insulated sediments over the basement rocks and post basin volcanic activities (Tanaka et al. 1999) and it can be inferred that the prospect areas in this study are in the southeastern, northeastern, southwestern, western and northwestern parts of the study area. The calculated geothermal gradient of the area is consistent with thermal gradient average of $23.56^{\circ} \mathrm{C} / \mathrm{km}$ measured from nineteen exploration wells within the Eastern Niger Delta Basin by Emujakporue and Ekine (2014). The areas with thick sediment cover, little to no evidence of volcanic activities and high heat flow could be geothermal sources and reservoirs and can be of help in identifying the existence of productive oil reservoirs at attractive temperature and depth in the study area. Curie point depths are inversely proportional to heat flow values as observed in Back Arc and Young Volcanic Regions (Yamano, 1995); therefore areas of shallow Curie point depth of about $21.15 \mathrm{~km}$ have geothermal potentials which can be utilized, with the zones labelled GP1, GP2, GP3, GP4 and GP5 (Fig. 6b) being more vibrant.

The shallow magnetic sources delineated within some parts of the study area may be due to the activities in the basement complex of southeastern Nigeria and activities of the Santonian Orogeny. These tectonic activities account for the complex regional fracturing within the study area. Figure 4 shows two major fault systems with NE-SW trend within the study area. Magnetic lineament map (Ibe and Uche, 2018) shows major faults trending NE-SW direction with minor faults trending NW-SE and N-S directions within the neighboring Afikpo Basin. These trends are in conformity with the structural trends in the Niger Delta Basin, Anambra Basin, Afikpo Basin and Southern Benue Trough (Nwajide, 2013) and could serve as migratory pathway for hydrocarbon and/or hydrothermal fluid(s) in the area. Sediments with relatively higher geothermal gradients mature earlier (low oil window) than those with low gradient values (Nwankwo and Ekine, 2009). Therefore, high geothermal gradient enhances the early formation of oil at relatively shallow burial depths, but it causes the depth range of the oil window to be quite narrow, while low geothermal gradient causes the first formation of oil to begin at fairly deep subsurface levels, but makes the oil window to be quite broad (Anakwuba and Chinwuko, 2015).

Sediment covers at the northeastern, northwestern, western, southwestern and southeastern parts of the study area (Fig. 6) are generally thin, while other parts of the study area have sediment thicknesses that are moderate to high. Wright et al. (1985) showed that the minimum thickness of sediment required to achieve the threshold temperature of $115^{\circ} \mathrm{C}$ for the commencement of oil formation from organic remains would be $2.3 \mathrm{~km}$ when all other conditions for hydrocarbon accumulation are favourable and the average temperature gradient of $1^{\circ} \mathrm{C}$ for $30 \mathrm{~m}$ obtainable in oil rich Niger Delta is applicable. In line with this, for any place within the study area to be viable for hydrocarbon formation, the thickness of the sediment must be up to $2.3 \mathrm{~km}$ in addition to other conditions necessary for hydrocarbon formations. Based on the computed sedimentary thicknesses ranging from 7.84 to $13.38 \mathrm{~km}$, the delineated major faults with NE-SW trend, faults with NE-SW, NW-SE and N-S trends in the Niger Delta Basin, neighbouring Anambra Basin and Southern Benue Trough (Nwajide, 2013) and Afikpo Basin (Ibe and Uche, 2018), the computed geothermal gradient $\left(20.758-35.649{ }^{\circ} \mathrm{C} / \mathrm{km}\right)$ and the fractures which could serve as migratory pathway for hydrocarbon or hydrothermal fluid, the potential of hydrocarbon generation and accumulation is feasible in the study area. This study shows that the zones labelled HC1, HC2 and HC3 (Fig. 6b) in the northern, southern and eastern parts respectively have more potentials of hydrocarbon generation and accumulation than other zones.

\section{Conclusion}

This study delineated the basement or centroid depth, Curie point depth, the geothermal gradient and the corresponding mantle heat flow in the study area. The sediment is thickest within Ikot Ekpene, Mbak, Ibiono Ibom, Abak, Ikot Apan and west of Atani and Obinto Areas, and shallowest within Abak Ukpum, Nwaigwe, Achan Ika, Ika and east of Atani and Obinto Areas; and with a range of 7.84 to $13.38 \mathrm{~km}$ in the study area. The Curie point depths range from about 15.42 to $26.49 \mathrm{~km}$, with the shallowest depths delineated within Amawum, Ndoro, Isiala, Ogbuebule, and east of Uyo Areas; and deepest points within east of Ikono, north of Mbak and west of Abak Areas. The study shows region of high geothermal gradients at Amawum, Ndoro, Isiala, Ogbuebule, Uyo, Abak Ukpum, Nwaigwe, Ika and east of Atani Areas and low geothermal gradients at east of Ikono, north of Mbak, west of Abak, Ikot Ekpene and Nung Idio Areas; and with a range of $20.758-35.649{ }^{\circ} \mathrm{C} / \mathrm{km}$ in the study area. Based on the computed sedimentary thicknesses, high geothermal gradient and the 
delineated major faults and fractures which could serve as migratory pathway for hydrocarbon or hydrothermal fluid, the potential of hydrocarbon generation and accumulation is feasible in the study area with the northern, southern and eastern parts being more vibrant. The geothermal prospect areas are in the southeastern, northeastern, southwestern, western and northwestern parts of the study area.

\section{Acknowledgement}

We acknowledge the Nigerian Geological Survey Agency (NGSA) for the data used in this work.

\section{References}

[1] Akpabio, I.O. and Ejedawe, J.E. (2010). Thermal conductivity estimates in the Niger Delta using lithologic data and geophysical well logs. Current science, vol. 98 , no. 3, pp. 411 - 417.

[2] Anakwuba, E.K. and Chinwuko, A.I. (2015). One dimensional spectral analysis and Curie depth isotherm of Eastern Chad Basin, Nigeria. Journal of Natural Sciences Research, vol. 5, no. 19, pp. 14 - 22.

[3] Chapman, D.S. and Furlong, K.P. (1992). The thermal state of the lower crust. In: Fountain, D.M., Arculus, R.J. and Kay, R.M. (eds), Continental lower crust: Developments in geotectonics. Elsevier Science Publication Co Inc; pp. 179 - 199.

[4] Ekweozor, C.M. and Daukoru, E.M. (1994). Northern delta depobelt portion of the Akata- Agbada (1) Petroleum system, Niger Delta, Nigeria. In: Magom, L.B. and Dow, W.G. (eds), The petroleum system from source to trap. Tulso: American Association of Petroleum Geologists, Memoir 60, pp. 599 - 614. https://doi.org/10.1306/M60585C36.

[5] Emujakporue, G.O. and Ekine, A.S. (2014). Determination of geothermal gradient in the Eastern Niger Delta Sedimentary Basin from bottom hole temperatures. Journal of Earth Sciences and Geotechnical Engineering, vol. 4, no. 3, pp. 109 - 114.

[6] Fatoke, O.A. (2010). Sequence stratigraphy of the Pliocene-Pleistocene strata and Shelf-Margin Deltas of the Eastern Niger Delta, Nigeria. [dissertation]. Houston: University of Houston.

[7] Hisarli, Z.M. (1996). Determination of Curie point depths in Western Anatolia and related with the geothermal Areas. [dissertation]. Istanbul: Istanbul University University, Turkey.

[8] Hosper, J. (1965). Gravity field and structure of the Niger Delta, Nigeria, West Africa. Geological Society of America Bulletin 76, pp. 407 - 422. https://doi.org/10.1130/0016-7606(1965)76[407:GFASOT]2.0.CO;2.

[9] Ibe, S.O. and Anekwe, U.L. (2018). Geophysical and geotechnical examination of structural failure in Federal University Otuoke. International Journal of Basic Science and technology, vol. 4, no. 2, pp. 42 - 52.

[10] Ibe, S.O. and Uche, I. (2018). Hydrocarbon potential of Nigeria's Inland Basin: case study of Afikpo Basin. Journal of Applied Geology and Geophysics, vol. 6 , no. 4, pp. 1-24.

[11] Jessop, A.M., Habart, M.A. and Sclater, J.G. (1976). The world heat flow data collection - 1975. Geothermal Service of Canada, series 5 , pp. 55 77. http://doi.pangaea.de/10013/epic.40176.d002.

[12] Kasidi, S. and Nur, A. (2012). Curie depth isotherm deduced from spectral analysis of magnetic data over Sarti and environs of North-Eastern Nigeria. Scholarly Journals of Biotechnology, vol. 1. No. 3, pp. 49 - 56.

[13] Kasidi, S. and Nur, A. (2013). Spectral analysis of magnetic data over Jalingo and environs North- Eastern Nigeria. International Journal of Science and Research, vol. 2, no. 2, pp. 447 - 454.

[14] Maden, N. 2009. Crustal thermal properties of the Central Pontides (Northern Turkey) deduced from spectral analysis of magnetic data. Turkish Journal of Earth Sciences, vol. 18, no. 3, pp. 383 - 392.

[15] Markku, P. 2014. FOURPOT. Potential field data processing and analysis of using 2-D Fourier transform. User's guide to version $1.3 \mathrm{a}$, pp. 1 - 54.

[16] Nur, A., Ofoegbu, C.O. and Onuoha, K.M. (1999). Estimation of the depth to the Curie point isotherm in the upper Benue Trough, Nigeria. Journal of Mining and Geology, vol. 35, no. 1, pp. 53 - 60.

[17] Nuri, D.M., Timur, U.Z., Mumtaz, H. and Naci, O. (2005). Curie point depth variations to infer thermal structure of the crust at the African- Eurasian convergence zone, SW Turkey. Journal of Earth, planets and Space, vol. 57, pp. 373 - 383. https://doi.org/10.1186/BF03351821.

[18] Nwajide, C.S. (2013). Geology of Nigeria's sedimentary basins. Lagos: CSS Bookshops Ltd. Chapter 11, Niger Delta Basin, pp. 347 - 518.

[19] Nwankwo, C.N. (2007). Heat flow studies and hydrocarbon maturation modeling in the Chad Basin Nigeria. [dissertation]. Port Harcourt: University of Port Harcourt, Nigeria.

[20] Nwankwo, C.N. and Ekine, A.S. (2009). Geothermal gradients in the Chad Basin, Nigeria, from bottom hole temperature logs. International Journal of Physical Sciences, vol. 4, no. 12, pp. 777 - 783.

[21] Nwankwo, C.N., Ekine, A.S. and Nwosu, I. (2009). Estimation of the heat flow variation in the Chad Basin Nigeria. Journal of Applied Sciences and Environmental Management, vol. 13, no. 1, pp. 73 - 80. https://doi.org/10.4314/jasem.v13i1.55276.

[22] Nwankwo, L.I., Olasehinde, P.I. and Akoshile, C.O. (2011). Heat flow anomalies from the spectral analysis of airborne magnetic data of Nupe Basin, Nigeria. Asian Journal of Earth Sciences, vol. 4, no. 1, pp. 20 - 28. https://doi.org/10.3923/ajes.2011.20.28.

[23] Nwankwoala, H.O. and Ngah, S.A. (2014). Groundwater resources of the Niger Delta: quality implications and management considerations. International Journal of Water Resources and Environmental Engineering, vol. 6, no. 5, pp. 155 - 163. https://doi.org/10.5897/IJWREE2014.0500.

[24] Okubo, Y., Graf, R.J., Hansen, R.O., Ogawa, K. and Tsu, H. (1985). Curie point depths of the Island of Kyushu and surrounding areas, Japan. Geophysics, vol. 53, no. 3, pp. 481 - 494. https://doi.org/10.1190/1.1441926.

[25] Okubo, Y., Matsushima, J. and Correia, A. (2003). Magnetic spectral analysis in Portugal and its adjacent seas. Physics and Chemistry of the Earth, vol. 28, no. 9, pp. 511 - 519. https://doi.org/10.1016/S1474-7065(03)00070-6.

[26] Okubo, Y., Tsu, H. and Ogawa, K. (1989). Estimation of Curie point temperature and geothermal structure of Island arc of Japan. Tectonophysics, vol. 159, no. 3-4, pp. 279 - 290. https://doi.org/10.1016/0040-1951(89)90134-0.

[27] Onwuemesi, A.G. (1997). One dimensional spectral analysis of aeromagnetic anomalies and Curie depth isotherm in the Anambra Basin of Nigeria. Journal of Geodynamics, vol. 23, no. 2, pp. 95 - 107. https://doi.org/10.1016/S0264-3707(96)00028-2.

[28] Osakuni, M.U. and Abam, T.K.S. (2004). Shallow resistivity measurement for cathodic protection of pipelines in the Niger Delta. Environmental Geology, vol. 45 pp. 747 - 752. https://doi.org/10.1007/s00254-003-0916-9.

[29] Short, K.C. and Stauble, A.J. (1967). Outline of the geology of the Niger Delta. American Association of Petroleum Geologists Bulletin 51, pp. 761 - 779. https://doi.org/10.1306/5D25C0CF-16C1-11D7-8645000102C1865D.

[30] Spector, A. and Grant, F.S. (1970). Statistical models for interpretation of aeromagnetic data. Geophysics, vol. 35, no. 2 , pp. 197 - 359 https://doi.org/10.1190/1.1440092.

[31] Stefan, M. and Vijay, D. (1996). Depth estimation from the scaling power spectrum of potential fields. Geophysical Journal International, vol. 124, no. 1, pp. 113 - 120. https://doi.org/10.1111/j.1365-246X.1996.tb06356.x.

[32] Tanaka, A., Okubo, Y. and Matsubayashi, O. (1999). Curie point depth based on spectrum analysis of the magnetic anomaly data in East and Southeast Asia. Tectonophysics, vol. 306, no. 3, pp. 461 - 470. https://doi.org/10.1016/S0040-1951(99)00072-4.

[33] Trifonova, P., Zheler, Z., Petrova, T. and Bojadgieva, K. (2009). Curie point depths of the Bulgrian territory inferred from geomagnetic observations and its correlation with regional thermal structure and seismicity. Tectonophysics, vol. 473, no. 3-4, pp. $362-374$. https://doi.org/10.1016/j.tecto.2009.03.014. 
[34] Tselentis, G.A. (1991). An attempt to define Curie depth in Greece from aeromagnetic and heat flow data. Pure and Applied Geophysics, vol. 136, pp. 87 - 101. https://doi.org/10.1007/BF00878889.

[35] Tuttle, M.L.W., Charpentier, R.R, Brownfield, M.E. (1999). The Niger Delta petroleum system: Niger Delta Province, Nigeria, Cameroon, and Equatorial Guinea, Africa. United State Geological Survey, Open-File Report, pp. 7 - 14. https://doi.org/10.3133/ofr9950H.

[36] Wright, J.B., Hastings, D.A., Jones, W.B. and Williams, H.R. (1985). Geology and Mineral Resources of West Africa. George Allen and Unwin, London. https://doi.org/10.1007/978-94-015-3932-6.

[37] Yamano, M. (1995). Recent heat flow studies in and around Japan. In: Gupta, M.L. and Yamano, M. (eds), Terrestrial heat flow and geothermal energy in Asia. Rotterdam: AA Balkema; pp. 173 - 201 